\title{
Economising Early Prints on Fight Books by Multiple Using Movable Half Page Woodcuts.
}

\section{Insights into the layout work on the illustrations of Andre Paurnfeindt's Fight Book of 1516 published by Hieronymus Vietor}

Matthias Johannes Bauer, University of Duisburg-Essen

\section{INTRODUCTION}

In 2016, this fight book has its 500-year-anniversary: Andre Paurnfeindt's Ergrundung Ritterlicher kunst der Fechterey [...] was published by the famous printing office of Hieronymus Vietor in Vienna in the year 1516. ${ }^{1}$ Except for three small wrestling early prints, Paurnfeindts publication is the earliest known printed fight book; ${ }^{2}$ in fact it is the first published one containing several treatises on different weapons. ${ }^{3}$ It is an unpaginated 40 folio quarto print (landscape format, ca. $19 \mathrm{~cm} \mathrm{x} \mathrm{ca.} 15 \mathrm{~cm}$ ) and it was produced in quite a handy size, thus. Only one single copy is known today; ${ }^{4}$ for a long time it had been missing ${ }^{5}$ probably due to a typo on the back of the book until Henk Pardoel found it in Glasgow. ${ }^{6}$

Only very little is known about the life of Paurnfeindt: He was from Ernstbrunn, a village in Lower Austria, about 40 kilometers north of Vienna. On October 13, 1512, he enrolled at Vienna University. As a foot soldier (trabandt) he was serving Mathäus Lang, bishop of

\footnotetext{
${ }^{1}$ For an introduction into Paurnfeindt's fight book, cf. Bauer, "Paurnfeindt, Andre(as)" and Bauer, "Paurnfeindts Fechtbuch: Nicht für die alten Fechter, sondern für die jungen Schüler".

2 Wrestling books published by Hans Wurm in Landshut about 1507 [38.10], one presumably by Matthias Hupfuff in Straßbourg, ca. 1510-12, and one by Hans Sittich in Augsburg, ca. 1512; cf. Leng, Fecht- und Ringbücher, p. 139.

${ }^{3}$ Cf. Leng, Fecht- und Ringbücher, p. 139-144.

${ }^{4}$ Glasgow, Culture and Sports (Museums), E.1939.65.357. -- Reprint: Verband, Paurnfeindts Fechtbuch aus dem Jahr 1516.

${ }^{5}$ Leng, Fecht- und Ringbücher, p. 141 ("Verbleib unbekannt"). His insufficient philological heuristic on finding and cataloguing any illustrated fight books was critically reviewed by: Welle, "Ordnung als Prinzip"; Bauer, "Rezension".

${ }^{6}$ Pardoel, Fencing. A Bibliography, p. 255 (there dated to 1561 as erroneously noted on the back of the book).
} 
Gurk and later archbishop of Salzburg (born 1468 in Augsburg, died 1540 in Salzburg). ${ }^{7}$ He calls himself a Freifechter, presumably meaning that he was a privileged fencer. ${ }^{8}$

There are some features that make Paurnfeindt's fight book very special amongst all other Early New High German fight books:

Firstly, it was completely set in humanistic minuscule which is not known for any other German fight book of that time period. ${ }^{9}$

Secondly, it is written for explicitly young students of the sword not for old masters. Thus, it was supposed to be a very basic introduction to fighting with the long sword, the 'Messer' (a specific single-handed single-edged melee weapon), and the quarterstaff. A short foreword of one page is followed by Zwoelff leren den angehnden Fechteren (twelve teachings to the novice fencer); the twelve leren (teachings) can be first found in this specific compilation with Andre(as) Paurnfeindt's Fight Book and might have been adopted from there into the Egenolff Fight Book ${ }^{10}$ and maybe also into Hans Czynner's Fight Book from $1538 .{ }^{11}$

Thirdly, it is striking for the printer and publisher economised this early print of a fight book by double using half page woodcuts and thereby reducing their number in total. This paper focuses on how this was done and discusses how effectively this work was.

\section{ECONOMISING WOODCUTS}

Additionally to the title woodcut, Paurnfeindt's fight book contains 34 full page woodcuts in total. ${ }^{12}$ They had been cut by an up to date still unidentified artist and artisan whose monogramme is "WAM" (woodcut no. 29; unpag. fol. 31v). ${ }^{13}$

${ }^{7}$ For Paurnfeindt's life, cf. Bauer, "Paurnfeindt, Andre(as)", and Bauer, "Paurnfeindts Fechtbuch: Nicht für die alten Fechter, sondern für die jungen Schüler".

8 Wassmannsdorf, "Ueber die Marxbrüder und Federfechter und über das älteste -- bisher noch unbekannte -- gedruckte deutsche Fechtbuch, p. 355, fn. 4”.

9 This is except for the term Ergrundung in the title which was set in a Gothic type. -- Around the middle of the 16th century Paulus Hector Mair used humanistic minuscule in his double volume fight books only for his Latin writing; cf. Munich, Bayerische Staatsbibliothek, Cod. Icon. 393, 1 \& 2 (manuscript only in Latin), and Vienna, Österreichische Nationalbibliothek, Cod. 10825/10826 (manuscript written bilingually in German and Latin).

10 Bauer, 'Der Allten Fechter gründtliche Kunst' - Das Frankfurter oder Egenolffsche Fechtbuch.

11 Graz, Universitätsbibliothek, M. 963, ed. by Bergner/Giessauf, Würgegriff und Mordschlag. An introduction to Hans Czynner in Bauer, "Czynner, Hans".

12 Leng, Fecht- und Ringbücher, p. 140. See the appendix in this paper for an overview.

13 For exchange of ideas on the monogramme I thank Dr. Ulrike Bayer (Munich), Dr. Dieter Beaujean (Berlin), and Dr. Rainer Welle (Ehrenkirchen-Norsingen). 
Usually a double page shows one woodcut on the left (verso folio) and the descriptive text on the right (recto folio). Eighteen of these woodcuts illustrate the first part about long sword fighting, twelve of them are placed in the 'Messer' fighting part and four show how to handle the quarterstaff.

Moreover, the woodcuts can be differentiated by two main characteristics. Either they show two fencers in fighting distance to each other before they will make a step or movement or they already moved in standing next to each other without any more distance. In the first case, both the fencers always stand near to the margins (21 non centered woodcuts; here henceforth designated type A) while in the second case they are placed in the middle of the woodcut (13 centered woodcuts; here henceforth designated type B). Two woodcut motifs were used twice, namely no. 5 (type B; same as no. 15) and no. 18 (type A; same as no. 20). ${ }^{14}$ But it seems, that in many instances only one half of a woodcut is repeating again and again in this early print. How is that?

On a close look, one will see that in fact not all of these illustrations are real full page woodcuts. Only the ones belonging to type B are made of one single printing plate, namely woodcuts no. 5 (=15), 8, 10,12,13, $15(=5), 22$, and 29 to 34 ; all other woodcuts were assembled by two movable half page printing plates put together to one single illustration (type A): movable woodcut printing plates like letters used in the mechanical movable type printing invented by Johannes Gutenberg. In some cases the junction points are even clear to see (no. 4, 6, 7, 9, 11, 14, 16, 17, 18, 19, 20, 21, 23, 26, 27) and in some cases horizon is only lined in one half of the illustration (no. 9, 11, 16, 19). This is a little irritating ... (see fig. 2).

${ }^{14}$ Cf. Appendix. 


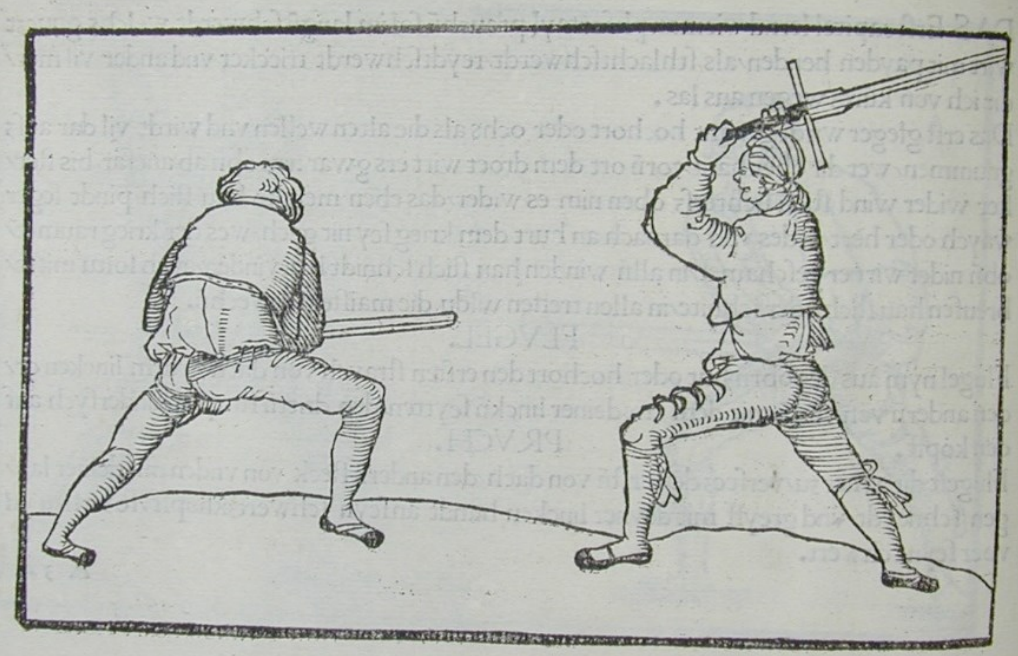

Fig. 1 Paurnfeindt's fight book from 1516: Both halves of woodcut no. 2 repeat three times within the entire fight book, yet in different combinations. (courtesy of Culture and Sports Glasgow (Museums), E.1939.65.357, unpaginated fol. $3 v$ ).

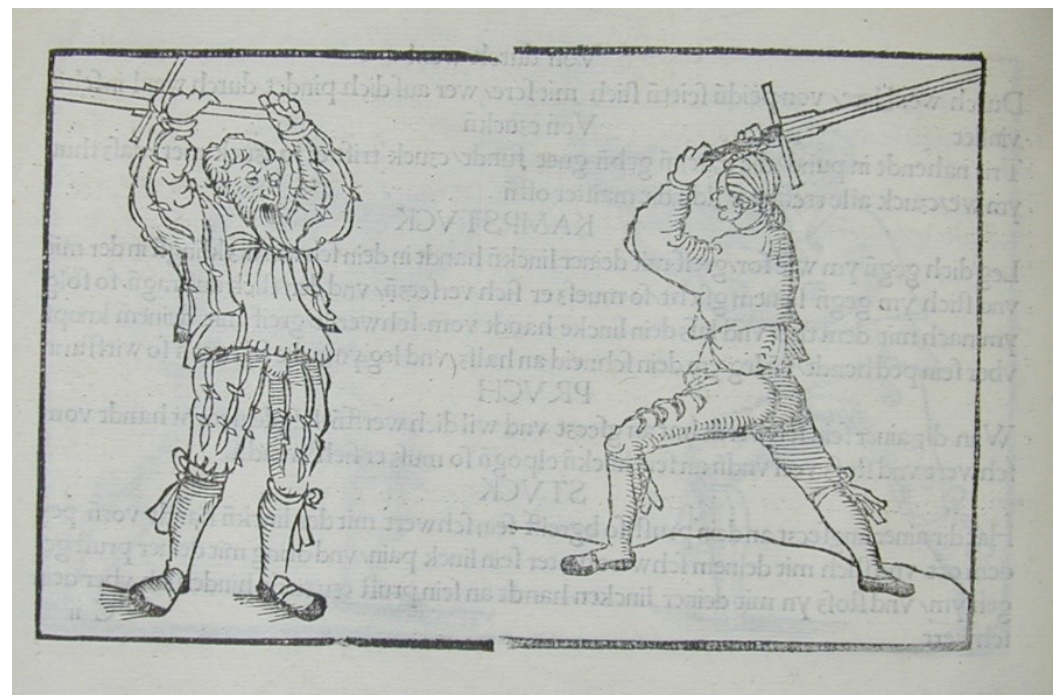

Fig. 2 Paurnfeindt's fight book from 1516: In woodcut no. 9 the junction points of the two half page printing plates are clear to see and horizon is only lined in one half of the illustration (courtesy of Culture and Sports Glasgow (Museums), E.1939.65.357, unpaginated fol. 10v). 
However, with this method it was possible to cleverly combine fewer available woodcut printing plates to more illustrations as such. Thus, some half plates were used up to four times: $: 15$

\begin{tabular}{|c|l|c|}
\hline Number of Usage & \multicolumn{1}{|c|}{ Woodcut Number (only half plates) } & Sum (total: 18) \\
\hline 4 times & 1 left, 3 left & 2 \\
\hline 3 times & 1 right, 2 left, 2 right, 3 right, 4 right, 6 right, 7 left & 7 \\
\hline 2 times & 9 left, 23 left, 23 right, 25 right & 4 \\
\hline 1 times & 24 left, 24 right, 25 left, 28 left, 28 right & 5 \\
\hline
\end{tabular}

Table 1: Number of usage of the balf plates

This method of combining motifs which repeat several times opened possibilities of economising the application of the woodcuts in Paurnfeindt's fight book. Instead of creating 32 individual woodcuts (i.e. 34 in sum minus two that repeat) the woodblock engraver only had to work twelve full page woodcut plates (i.e. 13 minus one that repeats) and 18 half page woodcut plates. That is much economy of effort, time and material. ${ }^{16}$

Only woodcuts no. 24 and 28 could have been alternatively worked from one full page printing plate either. And it is even not so clear whether they in fact are; they are the very only ambiguous types in the entire book that can not be matched with the one or the other type without doubt. If so, then there would be counted 14 half page and 15 full page woodcut printing plates. ${ }^{17}$ Still economically -- even when reducing the costs of illustrations by about one third must be seen in relation to all the remaining costs of the entire production. ${ }^{18}$

\section{CONCLUSION}

When Hieronymus Vietor printed and published Andre Paurnfeindt's fight book in the year 1516, it seems this project was economically well-thought-out -- particularly for the

\footnotetext{
${ }^{15}$ For this paper, I could not take a look into the original print. Therefore, I do not know whether the arrangement of the quires of the book had any influence on the repeating motifs: There always would be only one half plate available for both woodcut illustration on the very paper sheet.

16 This would come up to calculated 21 full page printing plate equivalents $(12 / 1+18 / 2=21)$ instead of creating 32 individual full page woodprints.

17 This would come up to calculated 22 full page printing plate equivalents $(15 / 1+14 / 2=22)$ instead of creating 32 individual full page woodprints.

18 Cf. Seelig, "Inkunabelillustration mit beweglichen Bildteilen", p. 123.
} 
repeating use of several full page woodcuts. ${ }^{19}$ Therefore, many of which were assembled from two half page printing plates that rendered many woodcuts possible for up to four applications within the very book. The fact that there is a new full page illustration of the same size as the text page area created out the combination of each two plates shows this was planned from the very beginning of the project. ${ }^{20}$ This includes the assumption that printing plates were probably sawed up not until the first usage within the printing process. ${ }^{21}$-- All this artistically is far beyond only combining woodcuts with various borders and frames although this might quite need somehow the same technical requirements. ${ }^{22}$

Surprisingly, the willingness to carve new half plates decreases with chapter to chapter. That is not only because the treatise on the long sword is the most extensive chapter. In the 'Messer' fighting part some woodcuts of the long sword chapter are reused although the weapons differ remarkably. ${ }^{23}$ In the chapter on the quarterstaff the weapon itself does not enable this method of combining two printing plates any more for the length of the weapon.

However, the idea of combining several two half size printing plates to create a much greater number of motifs was not new when Vietor and Paurnfeindt conceptualised their fight book. ${ }^{24}$ (And it even was some kind of old-fashioned when Paurnfeindt's fight book was translated into French and published with the same method of illustration under the title La Noble Science Des Ioueurs Despee in Antwerp in 1538. $)^{25}$

For example, about the year 1500 the Strasbourg printing office of Johann Grüninger multiple used the same woodcuts for two novels he produced parallely (Königstochter von Frankreich and Hug Schapler). ${ }^{26}$ As shown for Vietor and Paurnfeindt in this paper, Grüninger also increased the repeat rate of his half size woodcuts by combining them

${ }^{19}$ Maybe Paurnfeindt was already planning another project at that time: In his epilogue, Paurnfeindt announces a second book; but nothing of it is known today.

${ }^{20}$ Cf. Seelig, "Inkunabelillustration mit beweglichen Bildteilen", p. 106.

${ }^{21}$ Cf. ibid., p. 118.

22 Cf. ibid., p. 102.

23 That is why I don't think Paurnfeindt and Vietor reused several woodcuts primarily to show specific fencing techniques as precisely as possible without giving any unintentional variance; cf. Seelig, "Inkunabelillustration mit beweglichen Bildteilen", p. 132.

${ }^{24}$ For the exchange of ideas on further examples of early prints with movable woodcut printing plates I thank Dr. Oliver Duntze (Berlin), Dr. Florian Schmid (Greifswald), and Dr. Bettina Wagner (Munich).

25 After the first third of the 16th century this method is rarely seen, cf. Seelig, "Inkunabelillustration mit beweglichen Bildteilen", p. 133.

${ }^{26}$ Hagby, "History oder hübsches lesen?”. 
several times in both books but with highly varying quality. Apparently, in many cases Grüninger combined two motifs very hasty and inattentively: Often both printing plates do not fit aesthetically well (for an example see fig. 3).

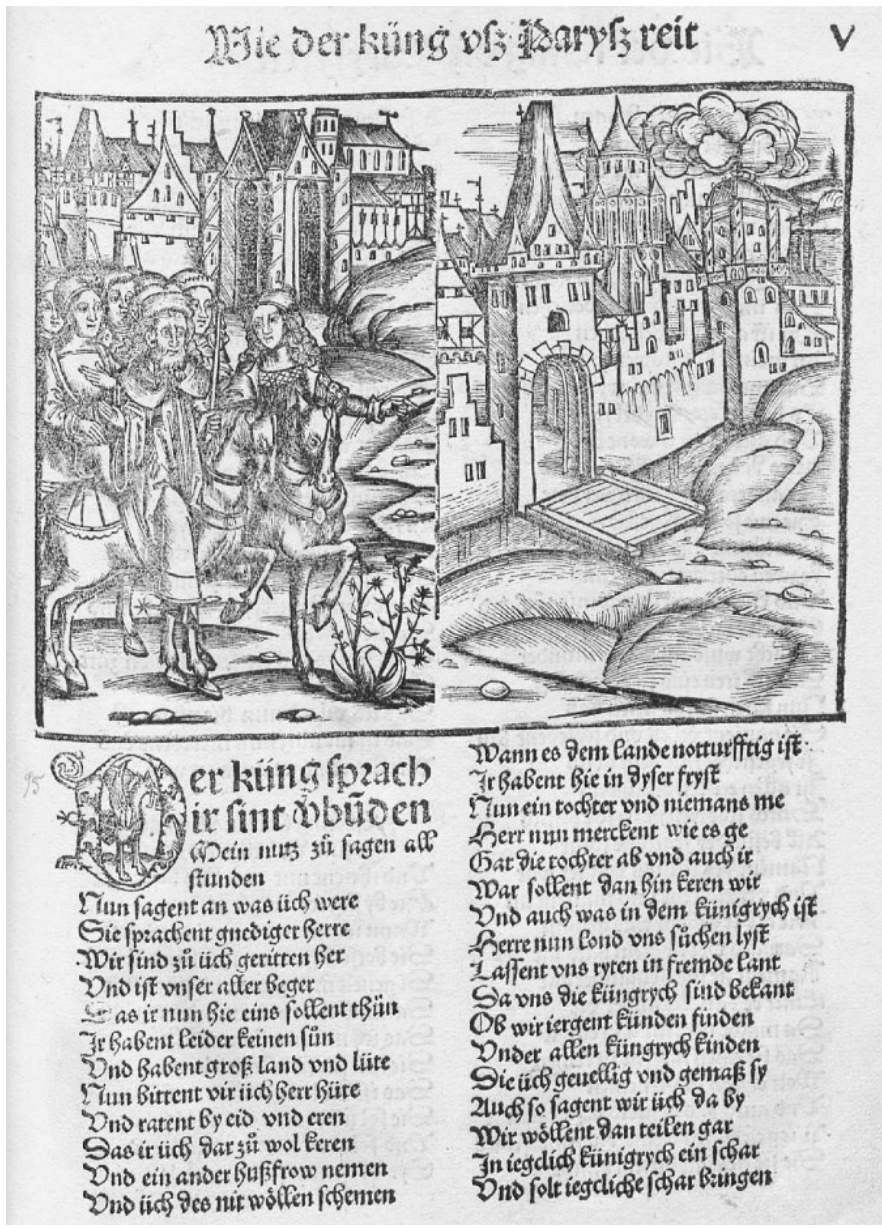

Fig. 3 Obviously hasty and inattentively combined woodcut of two half printing plates in 'Die Königstochter von Frankereich [...]' by Hans <von Bühel>, printed in Strassbourg in 1500 by Johann Grüninger (courtesy of Bayerische Staatsbibliothek. München and Münchener

DigitalisierungsZentrum Digitale Bibliothek, fol. $5 \mathrm{r}$ (bttp:/ / daten.digitalesammlungen.de $/ \sim d b / 0002 /$ bsb00027184/images $/$ index. html?id $=00027184$ \& nativeno $=5)$. 
This is unlike Paurnfeindt's fight book where the motifs are much more monotone (like the formulistic text itself, too! $)^{27}$ and therefore seem highly appropriate to such an economic method: In most cases there are only two fighters facing each other. This finds an analogy in Bartholomäus Kistler's book of St Hiob (printed by Kistler in 1498), where combined woodcuts usually show two protagonists in dialogue and where one half printing plate also is used for one of the two figures (see fig. 4 and 5). ${ }^{28}$

${ }^{27}$ Like most specialist literature, Early New High German fight books are characterized by very precisely phrased formulistic text, which I think the readers absolutely got used to. Therefore, variance maybe even was not desired either in the text or in the illustrations. Seelig, "Inkunabelillustration", p. 130, shows this on examples of juridical texts. For linguistic aspects of Early New High German fencing treatises see: Bauer, "Teaching How to Fight with Encrypted Words"; Bauer, "Fachsprache oder Geheimsprache?".

${ }^{28}$ Hieronymus, Sophronius Eusebius: Dises büchlein sagt von dem heyligen Job [...], Bartholomäus Kistler : Straßburg 1498; cf. Seelig, "Inkunabelillustration”, p. 117. 
Per groß

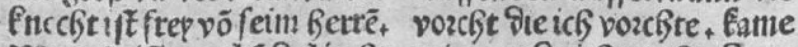

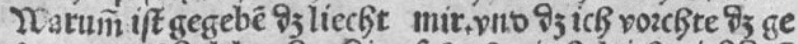

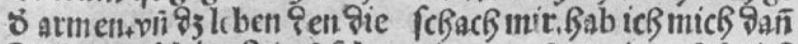
Oa fein in $\delta$ biteteit $\delta$ fele. nit aroer/z etzeiget Gab ick

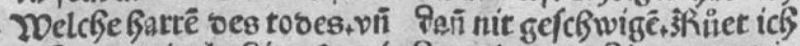

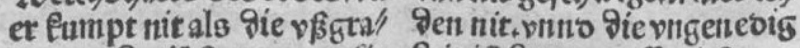

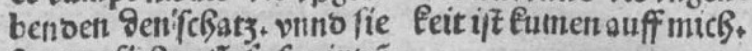
frewen fick valt tio fo vintoé

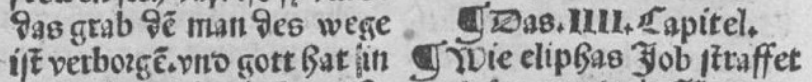

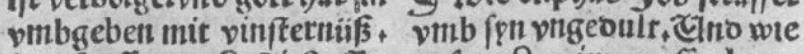

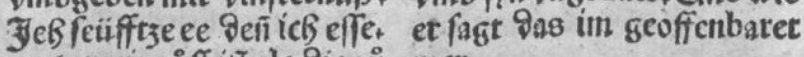
vuno mein riff iftals gie 3in wer.

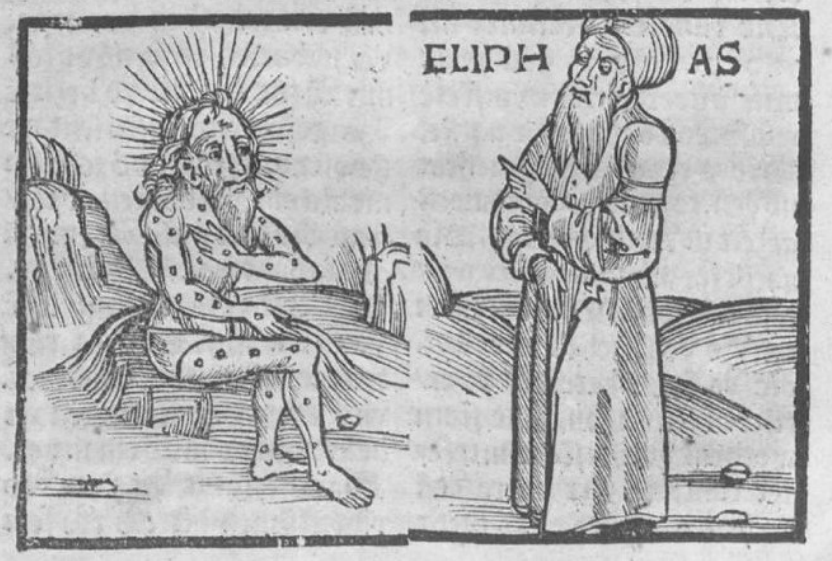

Fig. 4 Bartbolomäus Kistler's book of St Hiob (published 1498) usually shows two protagonists in dialogue, each cut from one balf printing plate (courtesy of Bayerische Staatsbibliothek. München and Münchener DigitalisierungsZentrum Digitale Bibliothek, unpaginated fol. (bttp:// daten.digitale-

sammlungen.de $/ \sim d b / 0008 /$ bsb00083108/images $/$ index. html? id $=00083108$ o groesser $=$ ¿ fip $=x d s y d e a y a x s x d s y d s d a s w x d s y d w x d s y d e a y a q r s q r s \& n o=111 \nLeftarrow$ seite $=20$ ). 
Sie ia waneri in Pent lótenín Bew/etn. Yie จิ ßabē Sie ir/ vifchen gruituelte fie werto verzeter als $v 0$ ö gen milbeit. fie wet'oéatgefçritể vö i̊

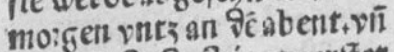
Garumb $8 j+93$ eeiner ver/fer fo weroé fyewigliç veroer berh roieaber íberig weroé

vie wetoé Gingerimmen $v / 3$ in. vilo weroen ferben viso nir in ier weypject.

a) $3 . V+$ Hapitel. Die elip 5 as iob fütter frtuf fet, vilo 3 i geoult vetmanet vinto was gitrat im จo von enfprunge.
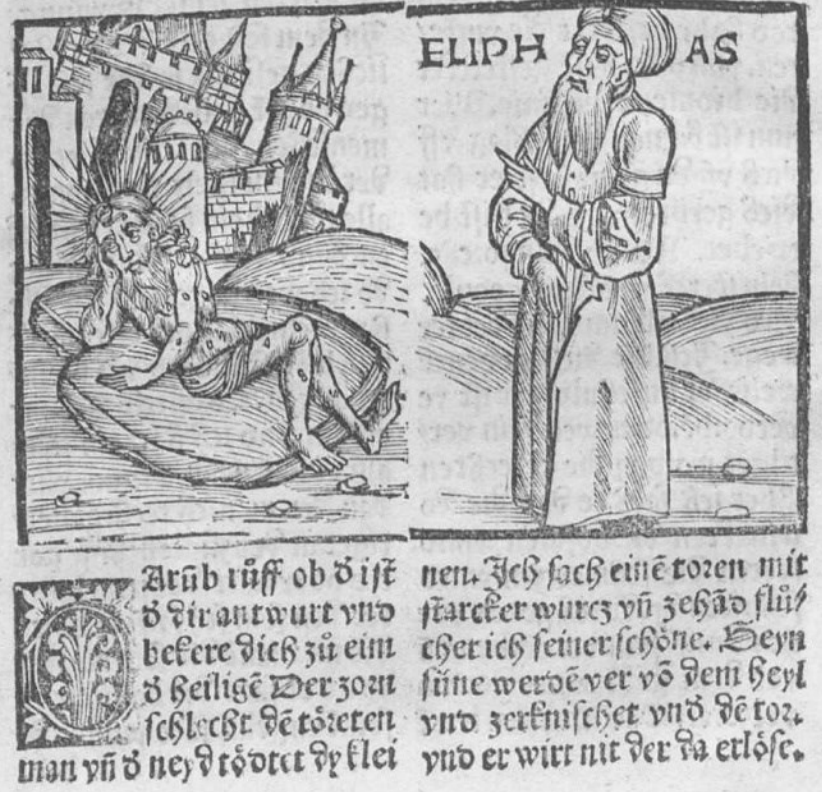

Fig. 5 Using one half printing plate for each protagonist on the woodcuts Kistler was easily able to repeat severe figures like the one of Eliphas (courtesy of Bayerische Staatsbibliothek. München and Münchener DigitalisierungsZentrum Digitale Bibliothek, unpaginated fol. (bttp:/ / daten. digitale-

sammlungen.de/ $\sim d b / 0008 /$ bsb00083108/images $/$ index. $b t m l ? i d=00083108$ \&groesser $=$ \&fip $=x d s y d e a y a x s x d s y d s d a s w x d s y d w x d s y d e a y a q r s q r s \& n o=113 \&$ seite $=22)$.

The simplicity of the woodcuts in the Paurnfeindt fight book are essential here because the except for some seldom horizon lines mostly plain background supports the opportunities of combining numerous half page printing plates. Somehow, the figures of the two fencers always seem to levitate without relating to any pictured environment which undoubtedly was a great advantage to this layout method. ${ }^{29}$ At the same time it is

${ }^{29}$ Cf. ibid., p. 111. 
important to understand that always both parts are indispensable for the content of the illustration as such. It might sound trivial, but one always will need exactly two figures to create the illustrated motif of a duel ...

\section{BIBLIOGRAPHY}

\section{IV.1. Primary sources (manuscript and print)}

Anonymous, [Wrestling book], Hans Sittich, Augsburg, ca. 1512.

Anonymous, [Wrestling book], Hans Wurm, Landshut, about 1507.

Anonymous, [Wrestling book], Matthias Hupfuff, Straßbourg, ca. 1510-12.

Graz, Universitätsbibliothek, M. 963 (Hans Czynner, [fight book], 1538); edition see secondary literature Bergner/Giessauf

Hieronymus, Sophronius Eusebius: Dises büchlein sagt von dem heyligen Job [...], Bartholomäus Kistler, Straßburg, 1498.

Munich, Bayerische Staatsbibliothek, Cod. Icon. 393, 1 \& 2 (Paulus Hector Mair, [fight book], middle of the 16th century).

Paurnfeindt, Andre(as), Ergrundung Ritterlicher kunst der Fechterey [...], Hieronymus Vietor, Vienna 1516 (only known copy: Glasgow, Culture and Sports (Museums), E.1939.65.357; Reprint see secondary literature Bauer).

Vienna, Österreichische Nationalbibliothek, Cod. 10825/10826 (Paulus Hector Mair, [fight book]).

\section{IV.2. Secondary literature}

Bauer, Matthias Johannes, "Czynner, Hans”, in Wolfgang Achnitz, ed., Deutsches LiteraturLexikon. Das Mittelalter, Autoren und Werke nach Themenkreisen und Gattun-gen, Band 7: Das wissensvermittelnde Schrifttum im 15. Jahrbundert (Berlin: De Gruyter, 2015), col. $1748 \mathrm{f}$.

Bauer, Matthias Johannes, Der Allten Fechter gründtliche Kunst' - Das Frankfurter oder Egenolfsche Fechtbuch. Untersuchung und Edition (München: Herbert Utz Verlag, 2016) [PhDthesis, Duisburg-Essen, Univ., 2016].

Bauer, Matthias Johannes, "Fachsprache oder Geheimsprache? Sondersprachliches in frühneuhoch-deutschen Ring- und Fechtlehren. Probleme und Perspektiven eines germanistischen Untersuchungs-ansatzes", Fachprosaforschung - Grenzüberscbreitungen, 4/5 (2008/09), 125-135

Bauer, Matthias Johannes, "Paurnfeindt, Andre(as)", in Wolfgang Achnitz, ed., Deutsches Literatur-Lexikon. Das Mittelalter, Autoren und Werke nach Themenkreisen und Gattun-gen, Band 
7: Das wissensvermittelnde Schrifttum im 15. Jahrhundert (Berlin: De Gruyter, 2015), col. 17401743.

Bauer, Matthias Johannes, "Paurnfeindts Fechtbuch: Nicht für die alten Fechter, sondern für die jungen Schüler", in Verband für Moderne Schwertkunst in Bayern e.V., ed., Paurnfeindts Fechtbuch aus dem Jabr 1516 (Nordstedt: Books on Demand, 2014), without page numbering.

Bauer, Matthias Johannes "Rezension", Beiträge zur Geschichte der deutschen Sprache und Literatur, 133 (2011), 510-4.

Bauer, Matthias Johannes, “Teaching How to Fight with Encrypted Words: Linguistic Aspects of German Fencing and Wrestling Treatises of the Middle Ages and Early Modern Times", in Daniel Jaquet, et al., eds., Late Medieval and Early Modern Fight Books. Transmission and Tradition of Martial Arts in Europe (14th-17th Centuries) (Leiden: Brill, 2016), p. 47-61

Bergner, Ute, and Johannes Giessauf, eds., Würgegriff und Mordschlag. Die Fecht- und Ringlehre des Hans Caynner (1538). Universitätsbibliothek Graz Ms. 963 (Graz: Adeva, 2009).

Hagby, Maryvonne, "History oder hübsches lesen? Beobachtungen zu den Straßburger Drucken der ,Königstochter von Frankreich“ und des ,Hug Schapler im Jahr 1500”, in: Karin Cieslik, Helge Perplies, and Florian Schmid, eds., Materialität und Formation. Studien zum Buchdruck des 15. bis 17. Jabrbunderts (Bremen: edition lumière, 2016), p. 39-59.

Leng, Rainer, Fecht- und Ringbücher (=Stoffgruppe 38 der Katalog der deutschsprachigen illustrierten Handschriften des Mittelalters, Band 4/2, Lieferung 1/2) (München: Beck, 2008).

Pardoel, Henk, Fencing. A Bibliography. Edition 01 ([Amsterdam], 2005).

Seelig, Gero, "Inkunabelillustration mit beweglichen Bildteilen", Gutenberg-Jahrbuch, 70 (1995), 102-134.

Wassmannsdorf, Karl, "Ueber die Marxbrüder und Federfechter und über das älteste -bisher noch unbekannte -- gedruckte deutsche Fechtbuch", Deutsche Turn-Zeitung, 45 (1864), 353-6.

Welle, Rainer, “Ordnung als Prinzip”, Medium Aevum Quotidianum, 59 (2009), 37-49. 


\section{APPENDIX}

All 34 woodcuts except for the title woodcut are counted from 1 to 34 . The content is given depending on which part of the book they are illustrating. Type A means non centered woodcuts assembled by two half page printing plates; type B are centered woodcuts made of one single printing plate. The arrangement of woodcuts follows the schematic: first appearance (numbers) plus ' $\mathrm{l}$ ' for left half page respectively ' $r$ ' for right half page if required for an A type woodcut.

\begin{tabular}{|c|c|c|c|}
\hline Woodcut No. & Contents & Type & Arrangement of Woodcuts \\
\hline 1 & Long Sword & $A$ & $1 / \times 1 r$ \\
\hline 2 & Long Sword & $A$ & $21 \times 2 r$ \\
\hline 3 & Long Sword & $A$ & $31 \times 3 r$ \\
\hline 4 & Long Sword & $A$ & $31 \times 4 r$ \\
\hline 5 (same as 15) & Long Sword & B & 5 \\
\hline 6 & Long Sword & $A$ & $11 \times 6 r$ \\
\hline 7 & Long Sword & $A$ & $71 \times 3 r$ \\
\hline 8 & Long Sword & B & 8 \\
\hline 9 & Long Sword & A & $91 \times 2 r$ \\
\hline 10 & Long Sword & B & 10 \\
\hline 11 & Long Sword & A & $21 \times 3 r$ \\
\hline 12 & Long Sword & B & 12 \\
\hline 13 & Long Sword & B & 13 \\
\hline 14 & Long Sword & $A$ & $11 \times 6 r$ \\
\hline 15 (same as 5) & Long Sword & B & 5 \\
\hline 16 & Long Sword & $A$ & $31 \times 2 r$ \\
\hline 17 & Long Sword & $A$ & $91 \times 1 r$ \\
\hline
\end{tabular}




\begin{tabular}{|c|c|c|c|}
\hline Woodcut No. & Contents & Type & Arrangement of Woodcuts \\
\hline 18 (same as 20) & Long Sword & A & $71 \times 4 r$ \\
\hline 19 & 'Messer' & A & $21 \times 6 r$ \\
\hline 20 (same as 18) & 'Messer' & A & $71 \times 4 r$ \\
\hline 21 (upside-down) & 'Messer' & A & $31 \times 1 \mathrm{r}$ \\
\hline 22 & 'Messer' & B & 22 \\
\hline 23 & 'Messer' & A & $231 \times 23 r$ \\
\hline 24 & 'Messer' & A & $24 \mathrm{I} \times 24 \mathrm{r}(24 ?)^{30}$ \\
\hline 25 & 'Messer' & A & $251 \times 25 r$ \\
\hline 26 & 'Messer' & A & $11 \times 23 r$ \\
\hline 27 & 'Messer' & A & $231 \times 25 r$ \\
\hline 28 & 'Messer' & A & $281 \times 28 r(28 ?)^{31}$ \\
\hline 29 & 'Messer' & B & 29 \\
\hline 30 & 'Messer' & B & 30 \\
\hline 31 & Quarterstaff & B & 31 \\
\hline 32 & Quarterstaff & B & 32 \\
\hline 33 & Quarterstaff & B & 33 \\
\hline 34 & Quarterstaff & B & 34 \\
\hline
\end{tabular}

${ }^{30}$ Not proven for not being repeated; could be one woodcut plate either.

31 Not proven for not being repeated; could be one woodcut plate either. 


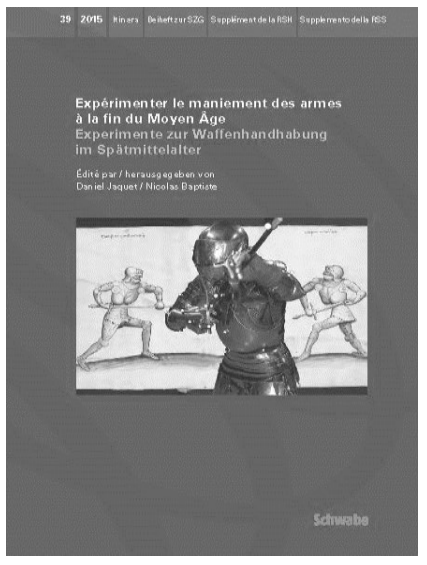

\title{
Daniel Jaquet and Nicolas Baptiste (eds),
} Expérimenter le maniement des armes à la fin du Moyen Age/Experimente zur Waffenhandhabung im Spätmittelalter (Itinera 39), Basel: Schwabe, 2016, 181 p. ISBN 978-3-7965-3467-6

Reviewed by Charlélie Berthaut

\author{
Université Paris 1, member of "AMHE Paris" \\ charlelie.berthaut@hotmail.fr
}

This book is drawn from a colloquium and is part of the collection "Itinera" of the Swiss Journal for History (Revue Suisse d'Histoire). It gathers the works of several authors from different horizons who share a common purpose: to prove that experimentation of technical combat gestures and their associated equipment can have a scientific method and become part of the academic field of research. The spectrum of the authors' profiles is broad: from academics researchers, historians (D. Jaquet, N. Baptiste, G. Martinez, P.-H. Bas, L. Forster), sociologists (A. Tuaillon-Demésy), and German philologists (T.Wilkens), to passionate amateur researchers (O. Gourdon, A. Selosse, S. Delachaux). At first, publishing professional and amateur work alongside may seem out of place but the seriousness and conscientiousness of the papers - professional and amateur alike - in this academic publication validates its plan. Two observations are to be found. The first one is that experimentation naturally arises from the study of fight books, military and martial material. The second is the fact that experimentation does not hold a strong place in academia. Here lies the brilliantly taken bet of this book. Experimentation already has a place in the Living History world, both for reenactment or Historical European Martial Arts (HEMA). Through the alliance of both professional and amateur researchers, this first of its kind piece of work acts as a stepping stone to rise experimentation to a scientific level. One may feel that the depth of potential still hiding behind its articles, asks to be better highlighted in the future. For this to happen, theoretical work, both methodological, epistemological, and practical work in establishing scientific experimental protocols are required. Both aspects are covered by the authors.

The book is divided into three distinct parts, each introduced by a theoretical article followed by articles with a more hands on approach.

The first part covering HEMA starts with an article by A. Tuaillon-Demésy who questions the idea of an "approach-process" ("démarche-processus"). She points out the vagueness of experimentation, considered as a common base, and identifies its multiple means and ends, from an ancient written martial art to a modern sport. Next, Thore Wilkens' article goes back over three publications (T. Stangier, 2009; J.-D. Müller, 1992; 
R. Welle, 1993), allowing him to put into perspective the absence of consideration for the fight books' practical function. He introduces prerequisites for a scientific experimentation as transparent as possible, supporting his assertions with the example of a wrestling play. The author hopes that such an approach may be taken for future fight book editions. The following article deals with gesture and combat technique for a foot soldiers, looking to answer questions risen from interrogations given by iconographic and textual sources from the $11^{\text {th }}$ to $13^{\text {th }}$ century. Gilles Martinez exposes a three step experimental methodology: historical analysis collects, studies, and problematizes sources; a pre-experimental cycle serves as a double doorway between the analysis and the experience itself, providing a first calibration; then, the experimental cycle proceeds to testing experiences which produce data that has to be processed and analysed with respect to the sources. The chapter ends with an article from P.-H. Bas which brings together two authors from the middle of the $16^{\text {th }}$ century: an Augsburger whose work is turned to the past, Paulus Hector Mair and the Roman Camillo Agrippa, innovator of his time. Between the practicality of Agrippa and the exhaustive ambition of Mair, the study of the technical plays' characteristics allows to identify their application context and their efficiency. The reading of these works leads us to the idea of a system, in which the two authors proceed to a reduction, in art for one, in science for the other. Finally, the article's author suggests to read Mair with Agrippa's scientificity to ascertain new understandings for experimentation.

The second part of the book starts with an article from Daniel Jaquet. The author explores the fight books' partition between armoured and unarmoured combat with a focus on kinesiology. The author's experimental protocol aims at two objectives: analysing energy expenditure previously studied - and limitation of movements in the three plans of space. He explores the latter with an armour made in accordance with experimental archaeology, and provides interpretations comforting the idea of a medieval technological, functional and well thoughtout armour. In the following article, Olivier Gourdon starts with collecting explicit and implicit comments about the cutting edge of the gladium emolutum from various sources (fight books particularly ms. I.33 (Leeds) -, legislative documents, archaeological material, iconography). After a precise description of the material that was used and of the test's course, the author analyses the cutting mechanisms (cut, gash, thrust, false or true edge) and target configurations (naked, covered in linen or leather). The experience's feedback clarifies the diverse historical vocabulary. Going back to the sources, Olivier Gourdon raises the question of the absence of a specific posture present in historical iconographies but absent of ms. I.33 to answer it by identifying this cut as an accessory tool in the making. The last article of the second part is about horse riding and its equipment, a specific discipline which increases the variables (horseman and mount) within the martial arts classification. Indeed, the horse riding art is not mentioned, thought as presupposed in the technical combat literature. The author, Lois Forster, studies the essential of the subject making the link between the two beings: the saddle. He mainly follows the king of Portugal Dom Duarte's technical work concerning different horse riding styles (Bravante, Gineta, bareback riding), to which he joins afterwards other 
iconographic and textual sources. From this, the author draws assumptions about medieval military horse riding which he goes on to experiment. Analysis of sources and experimentation allow for a critical look over previous studies on medieval horse riding.

The third and final part of the work starts with an article from Nicolas Baptiste. He goes over experimentation as practiced in exact sciences, which historians are not used to, and its link with historical commemorations and private collections. Retracing $19^{\text {th }}$ and $20^{\text {th }}$ century experiences aiming at reconstructing armours from between 1330 and 1530, he distinguishes science-based acts (hydraulic hammer in the abbey of Fontenay), those linked with cultural mediation (public demonstrations in Leeds) and private experiences (Tobias Capwell or Mike Loades). Additionally, the authors point out the issue of the actual "historical" tools - originals, copies and imitations -, the events that they crossed from their original condition. The author then lays out the required conditions for scientific experimentation and follows the course he believes it should follow. On this subject there are a lot of variations in personal experiences. The following article from Antoine Selosse is one of them and is about a military garment from the late Middle Ages: the brigandine. After referring to the historical preserved pieces and classifying them in three groups, the author sets out the steps of reconstructing a brigandine from analysing authentic pieces. After fifteen years of experiences with several reconstituted pieces for cultural events, he relates the findings, and shares his assumptions and thoughts. The book ends with the article of Simon Delachaux on the "Artillery Project" ("Projet Artillerie"), aiming at building a fifteenth-century artillery piece. The project came to be through the collaboration between living History practitioners and scientists, who noticed a lack of artillery pieces in re-enactment. Receiving support of heritage institutions, the project is growing in the long run. From the preserved pieces, the reconstitution grows in coordination with scientists, amateurs and selected craftsmen. Once completed, the reconstituted piece will be used by historians to study the construction and handling of artillery pieces during the late Middle Ages.

This work invites itself into the debate about the legitimacy and the scientificity of experimentation, by answering issues coming in the disciplinary field. Far from engaging in the debate, the book clearly announces its position over a number of different articles. It must be said that the study of combat gestures is particularly prone to this kind of research, as it belongs to a practical field. Gestural experimentation is inspired by the concept of experimental archaeology which suits the studies of fight books, and stands at the crossroads of history (social, cultural, of art, of techniques, etc.) and hands on practice. The work defies the historiography and the historical school of thought which denies experimentation as a scientific tool.

In front of the vast field of study, the authors introduce a thought linked to their respective speciality and exemplifying it with the help of experiences made after the establishment of a protocol. The collusion between academic and amateur researchers forges a strong link between all actors of the wider historical field but does bring doubts about the undertaking reinforced by the apparent lack of a common definition for 
experimentation. The variety of subjects leads the authors to give their own view on the matter. The emerging impression of fragility does not strengthen its argument for scientificity. Nonetheless, this only diversity demonstrates that Gestural experimentation has a plural definition and multiple potential applications.

One defines the words to use and delimits their object. The dangerous challenge to set up experimentation within the scientific field could not be conclusive without the conscience, clarity and objectivity that the authors have towards the limits of their subject. The many limits identified can push the reader to wonder about the validity of such an undertaking, its vulnerability and potential development. In order not to give way to a breach in scientificity, the authors prove themselves to be precise and develop their demonstrations with caution. Thus, the footnotes - varying from thirteen to fifty-seven - comfort the reader into the authors' projects and places his speech within a wider scientific and historiographic theory. The work's ambition would maybe have expected a more powerful anchorage in the historiography, either by longer footnotes or with a bibliography, which the reader could have expected.

The reader will appreciate the international nature that the book wants to follow: amidst francophone articles, a German article slips through and English summaries of each article concludes the book before the presentation of the authors.

Likewise, the close link to the documentary sources, as evident through the constant interactions between experimentation and historical sources, is a claimed marker of scientificity. Although some are confined to a purely illustrative function, fightbook images, diagrams and graphs - which are reminiscent of the so-called hard sciences - and photographs clarify and shed additional light on the authors' arguments.

Innovative in the field of study about the arts of combat, this gathering of articles carries a discourse with a strong scientific will within. Following a ternary plan, the book manages to join the scientific approach of experimentation (problem, protocol, experiences, results and data processing), with the historical object: the fighting arts and its offensive and defensive material. The limits are abundant, but the authors know how to identify them and stay on track in spite of them. The authors keep in sight the common objective to give experimentation its place in the field of the scientific research. The variety of approaches demonstrates the modular and plural nature of experimentation with its own tools, ready to be used in all areas where research calls it. This book will benefit historians, who will find arguments supporting the legitimacy of gestural experimentation, as well as amateurs who will find guidelines for defining and creating scientific experimentations.

To follow the words of the great historian and anthropologist Jean-Claude Schmitt - who prefaced this book -, "[...] they convinced me".

\footnotetext{
${ }^{1}$ SCHMITT Jean-Claude, "Préface", p. 6. (personal translation) : "[Si la démarche et son intitulé m'ont d'abord surpris,] ils m'ont convaincu”.
} 